\title{
Nicotinic and Muscarinic Agonists Stimulate Rapid Protein Kinase C Translocation in PC12 Cells
}

\author{
Robert O. Messing, Anne M. Stevens, Elizabeth Kiyasu, and Alisa B. Sneade \\ Department of Neurology and the Ernest Gallo Clinic and Research Center, University of California, San Francisco, \\ California 94110
}

Phosphoinositide hydrolysis, a major mechanism for signal transduction in neural cells, generates diacylglycerol, which can in turn activate protein kinase $\mathrm{C}$ (PKC). Although cholinergic agonists elicit phosphoinositide hydrolysis in neural tissues, little is known about activation of PKC by cholinergic agonists. PKC requires phosphatidylserine for activation, and in intact cells this lipid requirement is satisfied by binding of the enzyme to cell membranes. Therefore, in intact cells, activation of PKC is often associated with a decrease in cytosolic PKC activity accompanied by an increase in membrane-associated activity. We studied cholinergic-induced activation of PKC by examining changes in the subcellular distribution of the enzyme in PC12 cells treated with cholinergic drugs. Carbachol $(1 \mathrm{~mm})$ induced large and rapid increases in membrane-associated PKC activity; a maximal increase of $460 \%$ occurred after $5 \mathrm{sec}$ of incubation. Carbachol-induced PKC translocation was concentration-dependent, with a biphasic dose-response curve yielding approximate $E_{50}$ values of $10^{-6} \mathrm{M}$ and $10^{-4} \mathrm{M}$ for the high- and low-affinity components, respectively. Experiments with selective cholinergic agents demonstrated that both muscarinic and nicotinic receptors are involved in carbachol-induced PKC translocation, but the response is predominantly mediated by nicotinic receptor stimulation. Muscarinic-induced association of PKC with cell membrane fractions was resistant to extraction by chelators, whereas nicotinic-mediated membrane binding was partially reduced by homogenization of cells in the presence of EGTA. Omission of calcium from the incubation medium or chelation of calcium with EGTA completely blocked muscarinic- and nicotinic-induced translocation. In addition, the calcium channel blocker nifedipine reduced the nicotinic response by $60 \%$. These results indicate that carbachol-induced PKC translocation in PC12 cells is due mainly to activation of nicotinic receptors and is modulated by calcium influx through voltage-dependent calcium channels. These studies also suggest that stimulation of either nicotinic or muscarinic receptors generates diacylglycerol, which produces chelator-resistant binding of PKC to cell membranes.

Received Sept. 28, 1987; revised June 17, 1988; accepted July 12, 1988

This work was supported by Clinical Investigator Development Award NS01151 and a grant from the Alcoholic Beverage Medical Research Foundation (to R.O.M.) We wish to thank Drs. David A. Greenberg, Ivan Diamond, and Daria MochleyRosen for their many helpful suggestions and for reviewing the manuscript.

Correspondence should be addressed to Robert O. Messing, M.D., Building 1, Room 101, San Francisco General Hospital, San Francisco, CA 94110.

Copyright (C) 1989 Society for Neuroscience $0270-6474 / 89 / 020507-06 \$ 02.00 / 0$
Protein kinase $\mathrm{C}(\mathrm{PKC})$ plays a key role in signal transduction by hormones and neurotransmitters that activate phosphoinositide hydrolysis. Breakdown of phosphatidylinositol bisphosphate $\left(\mathrm{PIP}_{2}\right)$ generates the intracellular second messengers inositol trisphosphate, which mobilizes calcium from intracellular stores (Berridge and Irvine, 1984), and diacylglycerol, which activates PKC by increasing the affinity of the enzyme for calcium and phospholipid (Nishizuka, 1984). PKC requires phosphatidylserine for activation, and in intact cells this lipid requirement is satisfied by association of the enzyme with cell membranes during activation (Kishimoto et al., 1980). Thus, tumor-promoting phorbol esters, which potently stimulate the enzyme by substituting for diacylglycerol (Nishizuka, 1984), cause a dramatic decrease in cytosolic PKC activity accompanied by a large increase in membrane-bound activity (Kraft and Anderson, 1983). Translocation of PKC activity from cytosolic to membrane fractions of intact cells has also been observed following receptor-mediated $\mathrm{PIP}_{2}$ breakdown in some tissues (Liles et al., 1986; Niedel and Blackshear, 1986; TerBush and Holz, 1986), but receptor-mediated translocation has been more difficult to demonstrate than phorbol ester-induced translocation (Niedel and Blackshear, 1986).

Muscarinic cholinergic receptors are coupled to $\mathrm{PIP}_{2}$ hydrolysis in brain and in several neural cell lines (Fisher and Agranoff, 1987). Certain neural responses to muscarinic stimulation appear to be mediated by PKC since they can be reproduced by treatment with phorbol esters. Such responses include inhibition of calcium-activated potassium currents in hippocampus ( $\mathrm{Ma}$ lenka et al., 1986), blockade of the inhibitory effects of adenosine and $\mathrm{GABA}_{\mathrm{B}}$ receptor stimulation in hippocampus (Worley et al., 1987), and down-regulation of muscarinic receptors in the neuroblastoma cell line N1E-115 (Liles et al., 1986). In N1E115 , muscarinic stimulation is also associated with translocation of PKC activity to the cell membrane (Liles et al., 1986). Although nicotinic agonists stimulate phosphoinositide hydrolysis and PKC association with cell membranes in adrenal medullary cells (TerBush and Holz, 1986; Eberhard and Holz, 1987) and chick embryo myotubes (Adamo et al., 1985; Eusebi et al., 1987), nicotinic-mediated phosphoinositide turnover and PKC activation have not been clearly demonstrated in neural cells.

PC12 is a cell line that allows the study of both nicotinic and muscarinic modulation of PKC. PC12 cells express muscarinic receptors coupled to PIP $_{2}$ hydrolysis (Vicentini et al., 1986) and nicotinic receptors that resemble neuronal nicotinic receptors both in their resistance to $\alpha$-bungarotoxin blockade (Patrick and Stallcup, 1977) and in their cross-reactivity with monoclonal antibodies to brain nicotinic receptors (Whiting et al., 1987). 
PC1 2 cells treated with nerve growth factor (NGF) develop morphologic and biochemical characteristics of mature sympathetic neurons (Greene and Tischler, 1976; Dichter et al., 1977). NGF-differentiated PC1 2 cells express increased numbers of muscarinic receptors (Jumblatt and Tischler, 1982) and are more responsive to nicotinic stimuli (Amy and Bennett, 1983). Phorbol esters evoke a variety of responses in PC1 2 cells, including neurotransmitter release (Pozzan et al., 1984; Matthies et al., 1987), inhibition of voltage-dependent calcium uptake (Di Virgilio et al., 1986; Harris et al., 1986; Messing et al., 1986), and inhibition of muscarinic-induced phosphoinositide hydrolysis (Vicentini et al., 1985a). In addition, phorbol ester treatment causes PKC translocation to $\mathrm{PC} 12$ cell membranes (Matthies et al., 1987). In this report, we use NGF-differentiated PC1 2 cells as a model neural system to study cholinergic modulation of PKC. The results provide evidence for both nicotinicand muscarinic-mediated activation of PKC in neural cells; they also indicate a role for voltage-sensitive calcium channels in mediating the nicotinic response.

\section{Materials and Methods}

Materials. DEAE cellulose (DE52) and P81 cellulose phosphate paper were purchased from Whatman. $\left[\gamma_{-32}{ }^{32}\right]$ ATP was from Amersham. Phosphatidylserine was purchased from Avanti Polar Lipids. Histone III-S, sn-1,2 dioleoylglycerol ( $\left.\mathrm{diC}_{18: 1}\right)$, carbachol, muscarine, leupeptin, phenylmethylsulfonyl fluoride (PMSF), 1,1-dimethyl-4-phenyl piperazinium iodide (DMPP), atropine, mecamylamine, and nifedipine were obtained from Sigma. NGF (2.5 S) was a gift from Dr. William Mobley.

Cell culture. PC12 cells were maintained at $37^{\circ} \mathrm{C}$ in a humidified atmosphere of $90 \%$ air and $10 \% \mathrm{CO}_{2}$ in Dulbecco's modified Eagle's medium (DMEM) containing 10\% horse serum, $5 \%$ fetal calf serum, 50 $\mathrm{U} / \mathrm{ml}$ penicillin, $50 \mu \mathrm{g} / \mathrm{ml}$ streptomycin, and $2 \mathrm{~mm}$ glutamine. Cells were subcultured onto collagen-coated $100 \mathrm{~mm}$ plastic dishes (Falcon) in medium supplemented with $50 \mathrm{ng} / \mathrm{ml}$ of $2.5 \mathrm{~S} \mathrm{NGF}$ at a plating density of $3 \times 10^{6}$ cells per dish. Medium was changed 3 and $6 \mathrm{~d}$ after subculturing, and experiments were performed on day 7 .

Subcellular fractionation. Cells were rinsed once in DMEM, preincubated at $37^{\circ} \mathrm{C}$ for $5 \mathrm{~min}$ in $4 \mathrm{ml}$ of DMEM, and incubated at $37^{\circ} \mathrm{C}$ for various times in $4 \mathrm{ml}$ of fresh DMEM containing indicated drugs. Incubations were terminated by aspirating the medium, rinsing once with $4 \mathrm{ml}$ of ice-cold buffer containing $250 \mathrm{~mm}$ sucrose, $1 \mathrm{~mm}$ EDTA, $1 \mathrm{~mm}$ EGTA, and $20 \mathrm{~mm}$ Tris- $\mathrm{HCl}(\mathrm{pH} 7.5)$, and scraping the cells from the dishes in $4 \mathrm{ml}$ of $20 \mathrm{~mm}$ Tris- $\mathrm{HCl}\left(\mathrm{pH} 7.5,4^{\circ} \mathrm{C}\right), 50 \mu \mathrm{g} / \mathrm{ml}$ leupeptin, and $1 \mathrm{~mm}$ PMSF. This process took approximately $25 \mathrm{sec}$ to complete. Thereafter, cells were kept on ice for up to $15 \mathrm{~min}$ during which time the subcellular distribution of PKC did not change. The samples were then homogenized on ice with 15 strokes of a tight-fitting teflon glass homogenizer, sucrose was added to a final concentration of $250 \mathrm{~mm}$, and the cells were homogenized with another 5 strokes. After centrifugation at $100,000 \times g$ for $60 \mathrm{~min}$ at $4^{\circ} \mathrm{C}$, the supernatant (cytosol fraction) was applied to a $200 \mu \mathrm{l}$ DE52 column $(0.9 \mathrm{~cm}$ diameter) equilibrated with buffer A containing $20 \mathrm{~mm}$ Tris- $\mathrm{HCl}\left(\mathrm{pH} 7.5\right.$ at $4^{\circ} \mathrm{C}$ ), 1 mM EDTA, 1 mM EGTA, 12 mM 2-mercaptoethanol, and 10\% glycerol. The column was washed with $2 \mathrm{ml}$ of buffer $\mathrm{A}$ and eluted batchwise with $2.5 \mathrm{ml}$ of buffer A containing $100 \mathrm{mM} \mathrm{NaCl}$. All PKC activity was found in this fraction. The pellet (crude membrane fraction) was solubilized for $1 \mathrm{hr}$ at $4^{\circ} \mathrm{C}$ in $4 \mathrm{ml}$ of buffer A containing 1\% Triton X-100 and centrifuged at $12,000 \times g$ for $10 \mathrm{~min}$ to remove insoluble material prior to DEAE chromatography, as described for the supernatant.

$P K C$ assay. The reaction mixture (final volume $100 \mu \mathrm{l}$ ) containcd 50 $\mu \mathrm{l}$ of sample, $24 \mu \mathrm{g}$ of phosphatidylserine, $0.8 \mu \mathrm{g}$ of $\mathrm{diC}_{18: 1}, 1 \mathrm{~mm} \mathrm{CaCl}_{2}$, $25 \mathrm{mM} \mathrm{MgCl}_{2}, 75 \mu \mathrm{g}$ of histone III-S, and $2 \mathrm{nmol}$ of [ $\gamma^{-32}$ P]ATP $(2-4$ $\times 10^{\mathrm{s}} \mathrm{dpm} / \mathrm{nmol}$ ). Lipids were prepared by sonication in $20 \mathrm{~mm}$ Tris$\mathrm{HCl}\left(\mathrm{pH} 7.5\right.$ at $\left.4^{\circ} \mathrm{C}\right)$. The reaction was started by adding $\mathrm{MgCl}_{2}$, histone, and $\left[\gamma^{-32} \mathrm{P}\right] \mathrm{ATP}$ at $30^{\circ} \mathrm{C}$ and was stopped after $3 \mathrm{~min}$ with $30 \mu \mathrm{l}$ of a solution containing $0.2 \mathrm{M}$ EDTA and $0.2 \mathrm{M}$ ATP. Aliquots of $100 \mu \mathrm{l}$ were spotted onto $2.5 \mathrm{~cm}^{2} \mathrm{P}-81$ cellulose phosphate papers. Papers were washed in water ( $10 \mathrm{ml}$ per paper) $4 \times$ and rinsed once in $95 \%$ ethanol prior to liquid scintillation counting. PKC activity was measured in triplicate samples as the difference between phosphorylation in the pres-
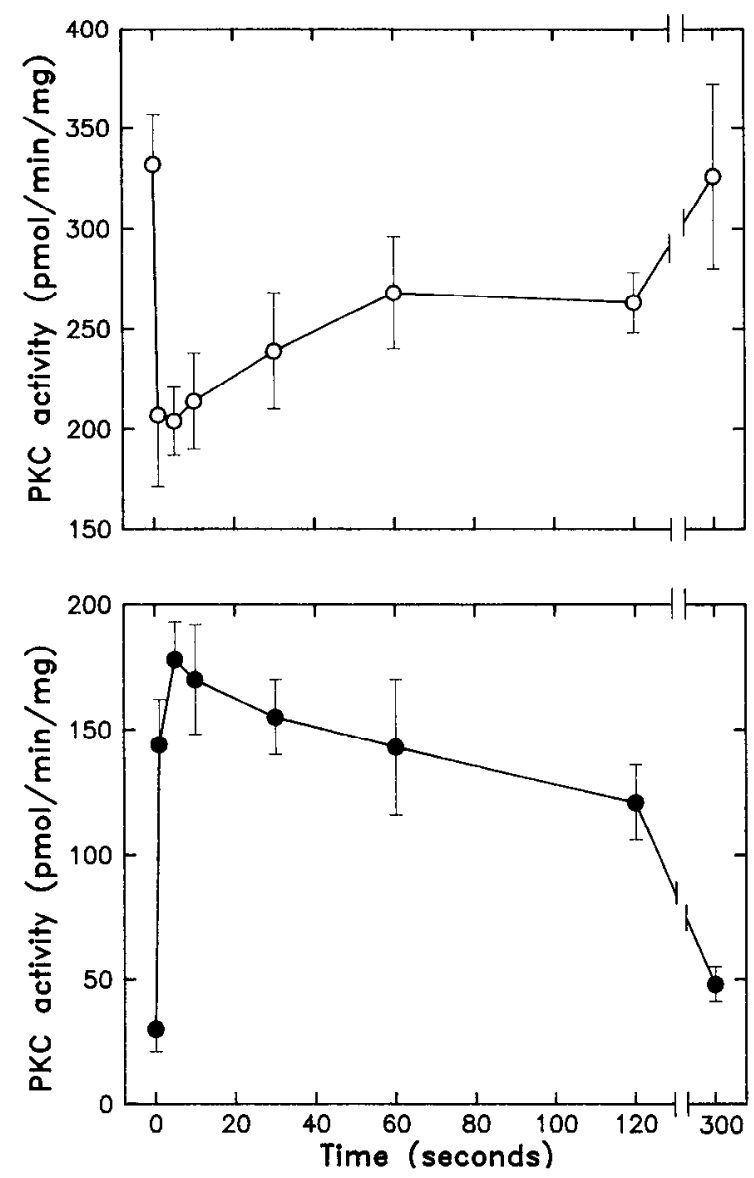

Figure 1. Time course of changes in the subcellular distribution of PKC in PC1 2 cells stimulated with $1 \mathrm{~mm}$ carbachol. Data shown are mean values \pm SEM from 3 experiments, expressed as enzyme activity present in the cytosolic $(O)$ or particulate (๑) fraction of cells per mg of cell protein.

ence and absence of phosphatidylserine, $\mathrm{diC}_{18: 1}$, and $\mathrm{Ca}^{2+}$. Enzyme activity was expressed as picomoles of ${ }^{32} \mathrm{P}$ incorporated per minute per milligram of cell homogenate. Results are reported in these units or as the percent of total PKC activity present in the membrane fraction. Protein was measured by the Bradford method (Bradford, 1976) with ovalbumin as the standard. Statistical comparisons between mean values were made by Student's $t$ test, and differences were considered significant where $p$ values $<0.05$ were found.

\section{Results}

PKC activity in unstimulated control PC12 cells was $336 \pm 17$ $\mathrm{pmol} / \mathrm{min} / \mathrm{mg}$ in the cytosol fraction and $77 \pm 6 \mathrm{pmol} / \mathrm{min} / \mathrm{mg}$ in the membrane fraction $(N=21)$. A similar predominance of cytosolic PKC activity has been noted in unstimulated cells from many other tissues (Nishizuka, 1984). As indicated in Figure 1, treatment of cells with $1 \mathrm{~mm}$ carbachol rapidly increased membrane-associated PKC activity. The effect was maximal by 5 $\mathrm{sec}$, producing a 4.6-fold increase in membrane-associated activity, and was accompanied by a corresponding decrease in cytosolic activity. Total (membrane-associated plus cytosolic) activity in carbachol-stimulated cells was $103 \pm 2 \%$ of total activity in control cells. Enzyme activity in the particulate fraction returned to levels equivalent to those found in unstimulated cells after $5 \mathrm{~min}$ of exposure.

The dependence of translocation on the concentration of carbachol is shown in Figure 2. Translocation occurred over a wide concentration range and the dose-response curve demonstrated 


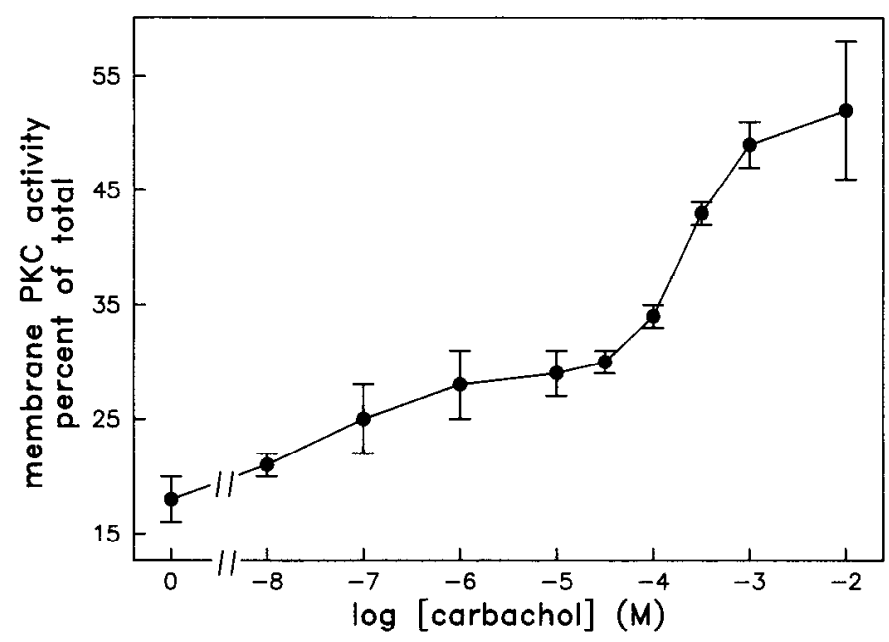

Figure 2. Stimulation of $\mathrm{PKC}$ translocation to $\mathrm{PC} 12$ membranes by incubation for $5 \mathrm{sec}$ with carbachol. Data shown are mean values \pm SEM from 3-6 experiments, expressed as the percent of total cellular PKC activity present in the particulate fraction.

2 phases, with apparent $\mathrm{EC}_{50}$ values of approximately $10^{-6} \mathrm{M}$ for the high-affinity and $10^{-4} \mathrm{M}$ for the low-affinity component. The high-affinity phase corresponds to the range of carbachol concentrations that produce muscarinic stimulation of phosphoinositide hydrolysis in PC12 (Vicentini et al., 1986). The low-affinity phase approximates the concentrations of carbachol that stimulate nicotinic-mediated ${ }^{22} \mathrm{Na}^{+}$(Patrick and Stallcup, 1977) and ${ }^{86} \mathrm{Rb}^{+}$(Robinson and McGee, 1985) uptake in PC12 cells.

Since carbachol is both a nicotinic and a muscarinic agonist, and since the concentration-response curve shown in Figure 2 was biphasic, we considered whether activation of both cholinergic receptor subtypes might bc involved in carbachol-induced translocation of PKC. As indicated in Figure 3, incubation of cells with $1 \mathrm{~mm}$ carbachol for $5 \mathrm{sec}$ resulted in a shift of PKC, activity such that $52 \pm 2 \%$ of total activity was associated with the particulate fraction. Muscarine stimulated PKC translocation maximally at $300 \mu \mathrm{M}$, but the response was only $24 \%$ of that observed with $1 \mathrm{~mm}$ carbachol. In contrast, a maximally effective concentration $(100 \mu \mathrm{M})$ of the selective nicotinic agonist DMPP nearly reproduced the response to carbachol. Atropine (100 nM), which completely inhibits muscarinic-stimulated phosphoinositide breakdown in PC12 (Vicentini et al., 1986), only slightly reduced the carbachol-stimulated increase in membrane PKC activity. In contrast, the nicotinic antagonist mecamylamine $(1 \mu \mathrm{M})$ was far more effective. The predominance of a nicotinic effect persisted at later time points as well, since at $2 \mathrm{~min}$ of incubation with $1 \mathrm{mM}$ carbachol, $1 \mu \mathrm{M}$ mecamylamine inhibited PKC translocation by $81 \pm 5 \%$, whereas $100 \mathrm{nM}$ atropine inhibited translocation by only $45 \pm 8 \%(N=3 ; p<0.02$ for inhibition by mecamylamine relative to inhibition by atropine). Neither atropine nor mecamylamine alone had any effect on PKC translocation (data not shown).

PKC activation and binding to cell membranes are modulated by calcium (May et al., 1985; Wolf et al., 1985; Gopalakrishna et al., 1986). Nicotinic receptor stimulation depolarizes cells, allowing for influx of extracellular calcium through voltage-dependent channels (Stallcup, 1979). Muscarinic stimulation activates a calcium influx in PC12 that is not dependent on depolarization and is resistant to organic calcium channel antagonist

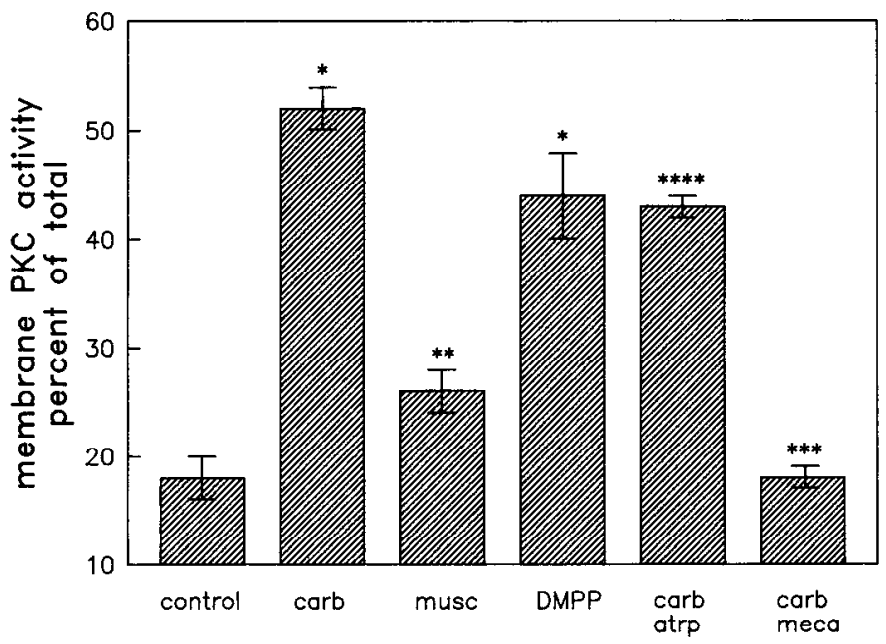

Figure 3. Effect of cholinergic agonists and antagonists on PKC translocation. Cells were preincubated with or without antagonists (atropine or mecamylamine) for $5 \mathrm{~min}$ and then incubated with indicated antagonists and agonists for $5 \mathrm{sec}$. Drugs were used at the following concentrations: 1 mM carbachol (carb), 1 mM muscarine (musc), $100 \mu \mathrm{M}$ DMPP, $100 \mathrm{~nm}$ atropine (atrp), and $10 \mu \mathrm{M}$ mecamylamine (meca). Data shown are mean values \pm SEM from 3-6 experiments, expressed as the percent of total activity present in the particulate fraction. $p<0.001\left(^{*}\right)$ and $p$ $<0.03{ }^{(* *)}$ relative to control; $p<0.001{ }^{(* * *)}$ and $p=0.05\left(^{* * * *}\right)$ relative to carbachol.

drugs (Pozzan et al., 1986). To determine whether influx of extracellular calcium is important in cholinergic-induced PKC translocation, we incubated cells with DMPP or muscarine in the presence and absence of calcium, EGTA, or the calcium channel antagonist, nifedipine. As shown in Figure 4 both muscarinic- and nicotinic-induced PKC translocation were completely inhibited in calcium-free buffer and in buffer containing 3 mM EGTA. Nifedipine (1 $\mu \mathrm{M})$, which completely blocks calcium influx through dihydropyridine-sensitive, voltage-dependent calcium channels in PC12 cells (Toll, 1982), inhibited maximal DMPP-induced translocation by approximately $60 \%$. In contrast, the response to muscarine was unaffected by nifedipine. Nifedipine alone had no effect on PKC translocation (data not shown).

Although calcium is required to initiate binding of $\mathrm{PKC}$ to cell membranes, binding induced by calcium alone is reversible and removed by extraction with calcium-chelating agents (Gopalakrishna et al., 1986). Phorbol esters and, to a lesser extent, diacylglycerol, stabilize membrane binding of the enzyme making binding resistant to removal by chelators (Gopalakrishna et al., 1986). To investigate whether cholinergic agonists caused membrane binding of PKC that was chelator-stable (i.e., due to calcium and diacylglycerol) or chelator-extractable (i.e., due only to elevated intracellular calcium), we compared cholinergic-induced PKC translocation in cells homogenized with and without 1 mM EGTA. As shown in Table 1, muscarine-induced translocation was unchanged by homogenization in EGTA, whereas DMPP-induced translocation was reduced $39 \%$ by this treatment. Since it was possible that $1 \mathrm{~mm}$ EGTA may not have chelated all of the calcium released during cell lysis, we also homogenized cells in $10 \mathrm{~mm}$ EGTA. Homogenization in $10 \mathrm{~mm}$ EGTA reduced membrane-associated PKC activity slightly further in control $(7 \pm 1 \%)$ and DMPP-treated cells $(19 \pm 2 \%)$, but the difference between these 2 values remained highly significant ( $p<0.007 ; N=3$ ). Therefore, both muscarine and 


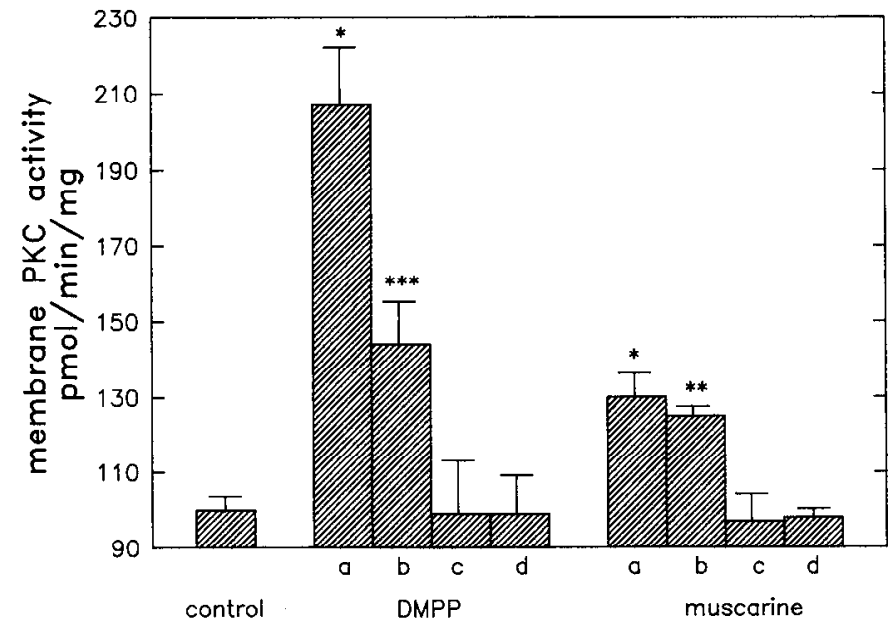

Figure 4. DMPP-and muscarine-stimulated PKC translocation in the presence and absence of calcium, nifedipine, and EGTA. PC12 cells were preincubated for $5 \mathrm{~min}$ in buffer containing $120 \mathrm{~mm} \mathrm{NaCl}, 5 \mathrm{~mm}$ $\mathrm{KCl}, 1.4 \mathrm{mM} \mathrm{CaCl}_{2}, 0.8 \mathrm{mM} \mathrm{MgSO}_{4}, 1 \mathrm{mM} \mathrm{NaH}_{2} \mathrm{PO}_{4}, 5 \mathrm{~mm}$ glucose, and 25 mM HEPES ( $\mathrm{pH}$ 7.4). Cells in condition $b$ were treated with 1 $\mu \mathrm{M}$ nifedipine during this period. Cells were then incubated for $5 \mathrm{sec}$ in the same buffer with agonist alone $(a)$, agonist plus $1 \mu \mathrm{M}$ nifedipine $(b)$, agonist plus 3 mM EGTA (c), or agonist without calcium $(d)$. Data shown are mean values \pm SEM from 3-6 experiments and are expressed as enzyme activity present in the particulate fraction per milligram of cell protein. Control values (in the absence of agonist) were equivalent in calcium-free and calcium containing buffers. $p<0.001\left(^{*}\right)$ and $p<0.03$ $\left({ }^{* *}\right)$ relative to control; $p<0.01\left({ }^{* * *}\right)$ relative to DMPP.

DMPP induced chelator-stable association of PKC with $\mathrm{PC} 12$ membranes.

\section{Discussion}

Our findings demonstrate that cholinergic stimuli induce rapid and marked increases in PKC activity in membranes of NGFdifferentiated PC1 2 cells. The effect was evident by $1 \mathrm{sec}$, suggesting a role for $\mathrm{PKC}$ in early neural responses to cholinergic signals. We found that $\mathrm{PKC}$ translocation occurred via both muscarinic and nicotinic receptor stimulation. In $\mathrm{PC} 12$, nicotinic stimuli induce the release of $\mathrm{ACh}$ (Greene and Rein, 1977a), but nicotinic-mediated $\mathrm{PKC}$ translocation cannot be attributed to $\mathrm{ACh}$ release and subsequent muscarinic receptor stimulation, since a maximally effective concentration of muscarine produced a smaller effect than carbachol and the response to carbachol was reduced only slightly by atropine. Nicotinic stimuli also cause the release of other neurotransmitters, such as catecholamines (Greene and Rein, 1977b), from PC12 cells. However, phosphoinositide breakdown and $\mathrm{PKC}$ activation have not been reported in $\mathrm{PC} 12$ cells exposed to noncholinergic neurotransmitters produced by this cell line. Therefore, it is likely that PKC translocation was a direct result of nicotinic receptor activation and was not mediated by released neurotransmitters.

Although both nicotinic and muscarinic agonists caused $\mathrm{PKC}$ translocation, we found the response to nicotinic stimuli to be much greater. The association of PKC with cell membranes requires calcium, and increases in calcium enhance membrane binding of the enzyme (Wolf et al., 1985; Gopalakrishna et al., 1986, Akers and Routtenberg, 1987). Calcium influx through dihydropyridine-sensitive calcium channels accounted for much of the difference between nicotinic and muscarinic responses, since nifedipine inhibited DMPP-induced translocation to levels
Table 1. Membrane binding of PKC in cells homogenized with and without $1 \mathrm{mM}$ EGTA

\begin{tabular}{lll} 
& \multicolumn{2}{l}{ Homogenization buffer } \\
\cline { 2 - 3 } Drug & No EGTA & 1 mM EGTA \\
\hline DMPP $^{a}$ & $41 \pm 4$ & $25 \pm 2$ \\
Muscarine & $23 \pm 1$ & $23 \pm 3$ \\
None & $14 \pm 1$ & $12 \pm 1$
\end{tabular}

Values are expressed as the percent of total PKC activity present in the particulate fraction.

a $p<0.02$ for cells homogenized in EGTA as compared to cells homogenized without FCrTA

observed with muscarine. The influx of calcium through dihydropyridine-insensitive calcium channels (Kongsamut and Miller, 1986) and through the nicotinic receptor (Stallcup, 1979) may explain why nifedipine failed to completely inhibit DMPPinduced translocation. In PC12 cells, muscarinic agonists elevate intracellular calcium by stimulating calcium influx through receptor-operated channels and inducing redistribution of calcium from cytoplasmic stores to the cytosol (Pozzan et al., 1986). However, the intracellular calcium concentration achieved with maximal muscarinic stimulation is only approximately one-half of that achieved by depolarization of PC12 cells (Pozzan et al., 1986). Therefore, nicotinic agonists, by depolarizing cells and stimulating calcium influx through voltage-dependent channels, may produce larger increases in intracellular calcium than do muscarinic agonists. Since the association of PKC with membranes varies with calcium concentration (Akers and Routtenberg, 1987), the higher concentrations of intracellular calcium achieved with nicotinic receptor stimulation may account for the greater extent of PKC translocation observed in cells treated with DMPP.

Although calcium is required for PKC binding to membranes, binding induced by calcium alone is reversible and is removed by calcium chelators (Gopalakrishna et al., 1986). In contrast, diacylglycerol, produced by phosphoinositide hydrolysis, stabilizes membrane binding of PKC so that binding becomes resistant to calcium-chelating agents (Gopalakrishna et al., 1986). We found that muscarine-induced translocation of $\mathrm{PKC}$ was entirely chelator resistant, suggesting that it is mediated by both diacylglycerol and calcium. In contrast, DMPP-induced translocation was partially reduced by homogenization in EGTA, suggesting that nicotinic-mediated binding of the enzyme to membranes involves two components, one mediated by calcium alone and the other by calcium and diacylglycerol.

The finding of chclator-stable binding suggests that nicotinicreceptor stimulation and the consequent rise in intracellular calcium may cause phosphoinositide hydrolysis and diacylglycerol formation in PC12 cells. Nicotinic-induced phosphoinositide hydrolysis has been demonstrated in adrenal chromaffin cells, where it is dependent on influx of extracellular calcium through voltage-dependent calcium channels (Eberhard and Holz, 1987). Therefore, in PC12 cells, phosphoinositide hydrolysis stimulated by depolarization-dependent calcium influx could be responsible for chelator-resistant association of PKC with membranes in cells treated with DMPP.

PKC tightly bound to PC12 membranes in the presence of both calcium and diacylglycerol is likely to be active. The functional state of PKC loosely bound to membranes by calcium 
alone may vary in different tissues. Elevated intracellular calcium may either directly activate PKC (Akers and Routtenberg, 1987) or may serve to recruit PKC to the cell membrane, thereby priming it for subsequent activation by diacylglycerol (May et al., 1985; Wolf et al., 1985). Since the majority of PKC associated with membranes after nicotinic stimulation was chelator sensitive, it is likely that calcium-mediated binding of PKC plays an important role in normal signal transduction.

When we incubated cells in the absence of extracellular calcium or in the presence of $3 \mathrm{~mm}$ EGTA, muscarine and DMPP were unable to stimulate PKC transloction. It is unlikely that this was due to inhibition of drug binding, since ligand binding to cholinergic receptors can be measured in the absence of calcium (Jumblatt and Tischler, 1982; Whiting and I indstrom, 1986). Prevention of extracellular calcium influx could explain the failure of DMPP to induce PKC translocation in cells incubated in calcium-free buffer. Incubation of PC12 cells in calcium-free buffer also inhibits muscarinic-stimulated calcium influx and can reduce muscarinic-induced $\mathrm{PIP}_{2}$ hydrolysis and intracellular calcium mobilization (Vicentini et al., 1985b; Rabe et al., 1987). A similar sensitivity of receptor-mediated phosphoinositide hydrolysis to external calcium concentration has been noted in other neural tissues (Fisher and Agranoff, 1987). Muscarinic stimulation of PC12 cells incubated in calcium-free buffer for 1 to 4 min increases intracellular calcium to only 100 $140 \mathrm{~nm}$ (Vicentini et al., 1985b, Rabe et al., 1987). Calcium at these concentrations does not enhance the association of PKC with rat brain synaptic membranes (Akers and Routtenberg, 1987) or erythrocyte vesicles (Wolf et al., 1985) in vitro. In our experiments, cells were exposed to calcium-free buffer for only $5 \mathrm{sec}$. Although this could block calcium influx, it is not known whether exposure for $5 \mathrm{sec}$ is sufficient to reduce muscarine-stimulated phosphoinositide hydrolysis. Nevertheless, we speculate that incubation of PC12 cells in calcium-free buffer inhibited extracellular calcium influx and may have reduced phosphoinositide hydrolysis, thereby preventing free intracellular calcium from reaching concentrations sufficient to initiate $\mathrm{PKC}$ translocation in response to muscarine. Further work is needed to determine the influence of calcium-free buffer on muscarine-induced phosphoinositide hydrolysis after brief (e.g., $5 \mathrm{sec}$ ) periods of exposure.

The finding of cholinergic-induced PKC translocation suggests that $\mathrm{PKC}$ is involved in rapid responses of PC12 cells to cholinergic stimuli. Such responses include neurotransmitter release (Greene and Rein, 1977b; Rabe et al., 1987) and c-fos proto-oncogene transcription (Greenberg et al., 1986), both of which can be induced by treatment with phorbol esters (Greenberg and Ziff, 1984; Pozzan et al., 1984). We (Messing et al., 1986) and others (Di Virgilio et al., 1986; Harris et al., 1986) have found that phorbol esters reduce voltage-dependent calcium influx in PC12, suggesting that activation of PKC inhibits the function of voltage-dependent calcium channels in this cell line. Rane and Dunlap (1986) reported similar findings in dorsal root ganglion cells treated with the PKC activator 1,2-oleoylacetylglycerol. These studies, together with our present findings, suggest that ACh may modulate the function of voltage-dependent calcium channels via PKC. The stimulatory effects of nicotinic agonists on voltage-dependent calcium channels and PKC suggest a mechanism whereby $\mathrm{PKC}$ could be involved in a negative-feedback response that inhibits calcium-channel function. Such a mechanism could be involved in the termination of nicotinic-induced calcium signals in neural tissues.

\section{References}

Adamo, S., B. M. Zani, C. Nervi, M. I. Senni, M. Molinaro, and F. Eusebi (1985) Acetycholine stimulates phosphatidylinositol turnover at nicotinic receptors of cultured myotubes. FEBS Lett. 190: 161-164.

Akers, R. F., and A. Routtenberg (1987) Calcium-promoted translocation of protein kinase $C$ to synaptic membranes: Relation to the phosphorylation of an endogenous substrate (protein F1) involved in synaptic plasticity. J. Neurosci. 7: 3976-3983.

Amy, C. M., and E. L. Bennett (1983) Increased sodium ion conductanec through nicotinic acetylcholine receptor channels in PC12 cells exposed to nerve growth factors. J. Neurosci. 3: 1547-1553.

Berridge, M. J., and R. F. Irvine (1984) Inositol trisphosphate, a novel second messenger in cellular signal transduction. Nature 312:315321.

Bradford, M. M. (1976) A rapid and sensitive method for the quantitation of microgram quantities of protein utilizing the principle of protein-dye binding. Anal. Biochem. 72: 248-254.

Dichter, M. A., A. S. Tischler, and L. A. Greene (1977) Nerve growth factor-induced increase in electrical excitability and acetylcholine sensitivity of a rat pheochromocytoma cell line. Nature 268: 501-504.

Di Virgilio, F., T. Pozzan, C. B. Wollheim, L. M. Vicentini, and J. Meldolesi (1986) Tumor promoter phorbol myristate acetate inhibits $\mathrm{Ca}^{2+}$ influx through voltage-gated $\mathrm{Ca}^{2+}$ channels in two secretory cell lines, PC12 and RINm5F. J. Biol. Chem. 261: 32-35.

Eberhard, D. A., and R. W. Holz (1987) Cholinergic stimulation of inositol phosphate formation in bovine adrenal chromaffin cells: Distinct nicotinic and muscarinic mechanisms. J. Neurochem. 49: 16341643 .

Eusebi, F., F. Grassi, C. Nervi, C. Caporale, S. Adamo, B. M. Zani, and M. Molinaro (1987) Acetylcholine may regulate its own nicotinic receptor-channel through the C-kinase system. Proc. R. Soc. Lond. 230: 355-365.

Fisher, S. K., and B. W. Agranoff (1987) Receptor activation and inositol lipid hydrolysis in neural tissues. J. Neurochem. 48: 9991017.

Gopalakrishna, R., S. H. Barsky, T. P. Thomas, and W. B. Anderson (1986) Factors influencing chelator-stable, detergent-extractable, phorbol dicster-induced membrane association of protein kinase $C$. J. Biol. Chem. 261: 16438-16445.

Greenberg, M. E., and E. B. Ziff (1984) Stimulation of 3 T 3 cells induces transcription of the c-fos proto-oncogene. Nature 311: 433-438.

Greenberg, M. E., E. B. Ziff, and L. A. Greene (1986) Stimulation of neuronal acetylcholine receptors induces rapid gene transcription. Science 234: 80-83.

Greene, L. A., and G. Rein (1977a) Synthesis, storage and release of acetylcholine by a noradrenergic pheochromocytoma cell line. Nature 268: 349-351.

Greene, L. A., and G. Rein (1977b) Release of $\left[{ }^{3} \mathrm{H}\right]$ norepinephrine from a clonal line of pheochromocytoma cells (PC.12) by nicotinic cholinergic stimulation. Brain Res. 138: 521-528.

Greene, L. A., and A. S. Tischler (1976) Establishment of a noradrencrgic clonal line of rat adrenal pheochromocytoma cells which respond to nerve growth factor. Proc. Natl. Acad. Sci. USA 73: 24242428.

Harris, K. M., S. Kongsamut, and R. J. Miller (1986) Protein kinase $\mathrm{C}$ mediated regulation of calcium channels in $\mathrm{PC}-12$ pheochromocytoma cells. Biochem. Biophys. Res. Commun. 134: 1298-1305.

Jumblatt, J. E., and A. S. Tischler (1982) Regulation of muscarinic ligand binding sites by nerve growth factor in $\mathrm{PCl} 2$ phaeochromocytoma cells. Nature 297: 152-154.

Kishimoto, A., Y. Takai, T. Mori, U. Kikkawa, and Y. Nishizuka (1980) Activation of calcium and phospholipid-dependent protein kinase by diacylglycerol, its possible relation to phosphatidylinositol turnover. J. Biol. Chem. 255: 2273-2276.

Kongsamut, S., and R. J. Miller (1986) Nerve growth factor modulates the drug sensitivity of ncurotransmitter release from PC12 cells. Proc. Natl. Acad. Sci. USA 83: 2243-2247.

Kraft, A. S., and W. B. Anderson (1983) Phorbol esters increase the amount of $\mathrm{Ca}^{2+}$, phospholipid-dependent protein kinase associated with plasma membrane. Nature 301: 621-623.

Liles, W. C., D. D. Hunter, K. E. Meier, and N. M. Nathanson (1986) Activation of protein kinase $C$ induces rapid internalization and subsequent degradation of muscarinic acetylcholine receptors in neuroblastoma cells. J. Biol. Chem. 261: 5307-5313. 
Malenka, R. C., D. V. Madison, R. Andrade, and R. A. Nicoll (1986) Phorbol esters mimic some cholinergic actions in hippocampal pyramidal neurons. J. Neurosci. 6: 475-480.

Matthies, H. J. G., H. C. Palfrey, L. D. Hirning, and R. J. Miller (1987) Down regulation of protein kinase $\mathrm{C}$ in neuronal cells: Effects on neurotransmitter release. J. Neurosci. 7: 1198-1206.

May, W. S., Jr., N. Sahyoun, M. Wolf, and P. Cuatrecasas (1985) Role of intracellular calcium mobilization in the regulation of protein kinase C-mediated membrane processes. Nature 317: 549-551.

Messing, R. O., C. L. Carpenter, and D. A. Greenberg (1986) Inhibition of calcium flux and calcium channel antagonist binding in the PC12 neural cell line by phorbol esters and protein kinase C. Biochem. Biophys. Res. Commun. 136: 1049-1056.

Niedel, J. E., and P. J. Blackshear (1986) Protein kinase C. In Phosphoinositides and Receptor Mechanisms, J. W. Putney, ed., pp. 4788 , Liss, New York.

Nishizuka, Y. (1984) The role of protein kinase $C$ in cell surface signal transduction and tumour promotion. Nature 308: 693-698.

Patrick, J., and B. Stallcup (1977) $\alpha$-bungarotoxin binding and cholinergic receptor function in a rat sympathetic nerve line. J. Biol. Chem. 252: 8629-8633.

Pozzan, T., G. Gatti, N. Dozio, L. M. Vicentini, and J. Meldolesi (1984) $\mathrm{Ca}^{2+}$-dependent and -independent release of neurotransmitters from PC1 2 cells: A role for protein kinase $\mathrm{C}$ activation? J. Cell Biol. 99: 628-638.

Pozzan, T., F. Di Virgilio, L. M. Vicentini, and J. Meldolesi (1986) Activation of muscarinic receptors in PC12 cells. Stimulation of $\mathrm{Ca}^{2+}$ influx and redistribution. Biochem. J. 234: 547-553.

Rabe, C. S., E. Delorme, and F. Weight (1987) Muscarine-stimulated neurotransmitter release from PC12 cells. J. Pharmacol. Exp. Ther 243: 534-541.

Rane, S. G., and K. Dunlap (1986) Kinase C activator 1,2-oleoylacetylglycerol attenuates voltage-dependent calcium current in sensory neurons. Proc. Natl. Acad. Sci. USA 83: 184-188.

Robinson, D., and R. McGee, Jr. (1985) Agonist-induced regulation of the neuronal nicotinic acetylcholine receptor of $\mathrm{PC1} 2$ cells. Mol Pharmacol. 27: 409-417.

Stallcup, W. B. (1979) Sodium and calcium fluxes in a clonal nerve cell line. J. Physiol. (Lond.) 286: 525-540.
TerBush, D. R., and R. W. Holz (1986) Effects of phorbol esters, diglyceride, and cholinergic agonists on the subcellular distribution of protein kinase $C$ in intact or digitonin-permeabilized adrenal chromaffin cells. J. Biol. Chem. 261: 17099-17106.

Toll, L. (1982) Calcium antagonists. High-affinity binding and inhibition of calcium transport in a clonal cell line. J. Biol. Chem. 257: 13189-13192.

Vicentini, L. M., F. Di Virgilio, A. Ambrosini, T. Pozzan, and J. Meldolesi (1985a) Tumor promoter phorbol 12-myristate, 13-acetate inhibits phosphoinositide hydrolysis and cytosolic $\mathrm{Ca}^{2+}$ rise induced by the activation of muscarinic receptors in PC12 cells. Biochem. Biophys. Res. Commun. 127: 310-317.

Vicentini, L. M., A. Ambrosini, F. Di Virgilio, T. Pozzan, and J. Meldolesi (1985b) Muscarinic receptor-induced phosphoinositide hydrolysis at resting cytosolic $\mathrm{Ca}^{2+}$ concentrations in PC12 cells. J. Cell Biol. 100: 1330-1333.

Vicentini, L. M., A. Ambrosini, F. Di Virgilio, J. Meldolesi, and T. Pozzan (1986) Activation of muscarinic receptors in PC12 cells. Correlation between cytosolic $\mathrm{Ca}^{2+}$ rise and phosphoinositide hydrolysis. Biochem. J. 234: 555-562.

Whiting, P., and J. Lindstrom (1986) Pharmacological properties of immuno-isolated neuronal nicotinic receptors. J. Neurosci. 6: 30613069.

Whiting, P. J., R. Schoepfer, L. W. Swanson, D. M. Simmons, and J. M. Lindstrom (1987) Functional acetylcholine receptor in $\mathrm{PCl} 2$ cells reacts with a monoclonal antibody to brain nicotinic receptors. Nature 327: 515-518.

Wolf, M., H. LeVine, W. S. May, Jr., P. Cautrecasas, and N. Sahyoun (1985) A model for intracellular translocation of protein kinase $\mathrm{C}$ involving synergism between $\mathrm{Ca}^{2+}$ and phorbol esters. Nature 317: 546-549.

Worlcy, P. F., J. M. Baraban, M. McCarren, S. H. Snyder, and B. E. Alger (1987) Cholinergic phosphatidylinositol modulation of inhibitory, $\mathrm{G}$ protein-linked, neurotransmitter actions: Electrophysiological studies in rat hippocampus. Proc. Natl. Acad. Sci. USA 84: 34673471 . 